\title{
COMPARISON BETWEEN EUROPEAN PROTESTANT AND CATHOLIC ECONOMIC DEVELOPMENT THROUGH MODERN PAINTING
}

\author{
AZ EURÓPAI PROTESTÁNS ÉS KATOLIKUS GAZDASÁGI \\ FEJLŐDÉS ÖSSZEHASONLÍTÁSA AZ ÚJKORI FESTÉSZET \\ TÜKRÉBEN
}

\begin{abstract}
Bernadett BALASSA ${ }^{\mathrm{a}}$
${ }^{a}$ Doctoral School of Regional and Economic Sciences, Széchenyi István University, Győr, Hungary, email: balassa.bernadett@sze.hu
\end{abstract}

Cite this article: Balassa, B. (2018). Comparison between European Protestant and Catholic Economic Development through Modern Painting. Deturope, 10(1), 82-96

\begin{abstract}
Since Max Weber, economists suggest that religious activity affects the European economic development, and this hypothesis was proven between the seventeenth and nineteenth centuries. Accordingly Protestant economic thinking accelerated the evolving system of capitalism, giving adequate attitudes to the accumulation of wealth. This research supposes that the mentioned capitalist approaches have their own impressions on visual arts, particularly on modern painting. It examines almost nine hundred religious paintings from the fifteenth to nineteenth centuries, investigating signs of business activities on the artworks. This form of qualitative examination apply the methodology of content analysis. As a result of the study the former hypothesis of Weber could be verified from multidisciplinary approach.
\end{abstract}

Key words: Spirit of capitalism, Protestant ethics, economic development, modern painting

\begin{abstract}
Absztrakt
Max Weber óta tudjuk, hogy a felekezeti hovatartozás befolyással bír egy térség gazdasági fejlődésére, legalábbis a 17. és 19. század közötti Európában ez a tétel igazoltnak látszik. Ennek megfelelően a protestáns gazdasági gondolkodás elősegítette a kapitalizmus születését, hiszen a korábbi világszemlélettől eltérő attitűdöket állított a vagyon felhalmozásának szolgálatába. Jelen tanulmány azt vizsgálja, nyomon követhetőek-e a protestáns és katolikus gazdasági gondolkodás különbségei a festészetben, és amennyiben igen, milyen következtetéseket vonhatunk le azokból. Az elemzési sokaság csaknem kilencszáz vallási témájú festményt tartalmaz, a mintába ebböl azok a müvek kerültek, amelyek gazdasági tevékenységet is megjelenítenek. A tanulmány kvalitatív kutatáson alapul, a tartalomelemzés technikáját alkalmazza. Az eredmények alapján Weber megállapításai az újkori festészet alapján is megerősíthetőek, a müvek gazdaságetikai különbségeket tükröznek.
\end{abstract}

Kulcsszavak: a kapitalizmus szelleme, protestáns etika, gazdasági fejlődés, újkori festészet

\section{INTRODUCTION}

According to Weber (1920) the spiritual reason for capitalism is Protestant ethic, while the materialistic origin was the capital accumulation after the Great Geographical Discoveries, 
and the reinforcement of private ownership. The Protestant Ethic and the Spirit of Capitalism argues that Protestant entrepreneurs created a brand new business atmosphere on the market. It connects economic activity with vocation (Luther) and the teaching of predestination (Calvin), putting profit maximization into a devotional level. Firstly, the solid work of man has become a concrete calling from God, which encouraged people to do their best in business life. This enterprising spirit and saving lifestyle characterized Protestants more than their Catholic fellows - argued Weber. In connection with predestination Calvin (1585:237-239) thought that every people had been concretely determined for the afterlife in Heaven or Hell before their birth, which exclude any human efforts to influence the quality of their afterlife. However economic success played a key role in their earthly lives, because it signaled that a person had been chosen for salvation (Barro \& McCleary, 2006:50), that is why Protestants were committed to gain more and more. Hard working and moderate lifestyle has led to wealth accumulation, hence the spirit of Protestantism contributed to the birth of capitalism referring to Weber.

\section{OBJECTIVES AND METHODS}

The first part of the publication processes secondary sources about the sociological relation between economy and religion. The questions are given: is it possible, that religious-based individual traits caused economic difference between Protestant and Catholic countries? how can we recognize the mentioned diverse attitudes and traits? This part of the paper provides empirical evidences for the distinct economic performance, which are explicable with Weber's theory (Weber, 1920). Besides statistical verification the main section of the study compares Italian and Dutch religious and economic themed paintings to explore the differences between Catholic and Protestant economic thinking. After this multidisciplinary examination the paper suggests some other explanations for the economic gap among European countries, between 1700 and 1950.

The aim of the publication is presenting the differences between Protestant and Catholic work ethic from fine arts of the modern period. In this way the study collects Bible-themed paintings between $15^{\text {th }}$ and $19^{\text {th }}$ centuries (888 pieces) and separates those ones which relay economic message (85 pieces). The method of the examination is content analysis. Contents are such human manifestations which are well documented, decipherable and the analysis is repeatable (Krippendorff, 1995). In a wider sense verbal and written communication, music, paintings or motions could be the subjects of content analysis. According to the suggestion of R. P. Weber (1985) the analyst could reveal by this method cultural characteristics, which are uneasy to examine by classical statistical techniques. Protestant and Catholic work ethic from 
historical aspect are much more undercover than analyze them with mainstream scientific methods - that is why the paper applies the alternative method of content analysis.

The contextual units of the analysis are Bible-themed paintings, exactly 888 pieces of European artworks from $15^{\text {th }}$ to $19^{\text {th }}$ centuries. In the process of data reduction I have examined all of them, than I have chosen those paintings which conclude economic contents. This narrowed database became the source of primer analysis. The study classifies these economic and religious themed artworks into four categories and quantifies the frequencies of each economic messages (categorized by 24 exclusive topics) readable from the paintings. Before describing the results of the examination the paper reviews historical connection between religious affiliation and economic development.

\section{THE ROLE OF RELIGION IN MODERN ECONOMIC DEVELOPMENT}

There is a wide discussion about the effects of religion on economic life (see Barro \& McCleary, 2003, 2006; Guiso et al. 2003, 2006), which could be a detailed topic of another paper. Nevertheless the strong correlation between Protestant dominance and the level of economic development is statistically detected (Young, 2009). According to historical GDP values from Maddison database Protestant countries had overtaken the Catholic world in terms of income from the $17^{\text {th }}$ till the middle of the $20^{\text {th }}$ century.

Figure 1 Religious divisions of Europe in the middle of 16th century

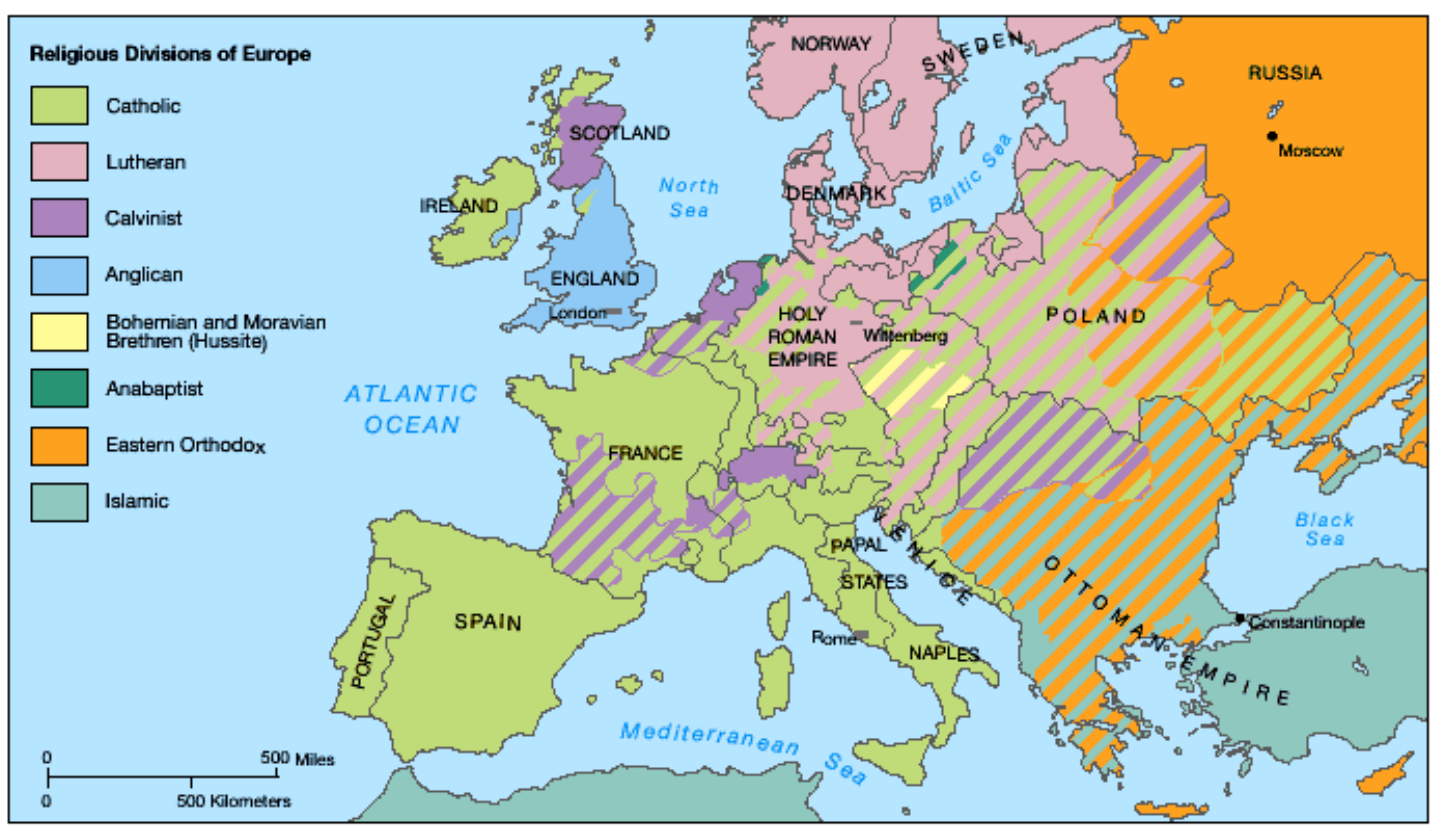

Source: Teacherweb 
Religious divisions of Europe in the middle of the $16^{\text {th }}$ century are shown in Fig. 1 . In the modern era many European countries preserved their Catholic majority. Mediterranean states, especially France, Venice, Naples and the Papal States were largely determined by this religion. North and Central parts of the Continent were influenced by reformers, the people of Netherlands and Scotland were Calvinists, the Holy Roman Empire and Scandinavian nations belonged mostly to Lutheran denominations. It signals rapid social transformation, because the population of these countries was all Roman Catholic prior to 1520 .

Besides religious statistics it is worth to study historical economic development of the mentioned states. Economic data about the modern history are available only as estimations in the Maddison database. Between the $15^{\text {th }}$ and $19^{\text {th }}$ centuries we know GDP per capita measures connected to seven Western European Catholic ${ }^{6}$ and eight Protestant ${ }^{7}$ countries. Those countries, which remained Catholic after the Reformation were traditionally the richer areas of Europe in the beginnings of the modern era. However - based on Young's (2009) calculation on the database - economic performance (GDP per capita) of Protestant countries has overtaken the same indicator of Catholic countries by 1700. This phenomenon was unusual, because formerly these eight states possessed more modest income than the other seven countries (Fig. 2).

Figure 2 Estimated GDP per capita (GK\$) in Protestant and Catholic Regions of Europe, $1500-1850$

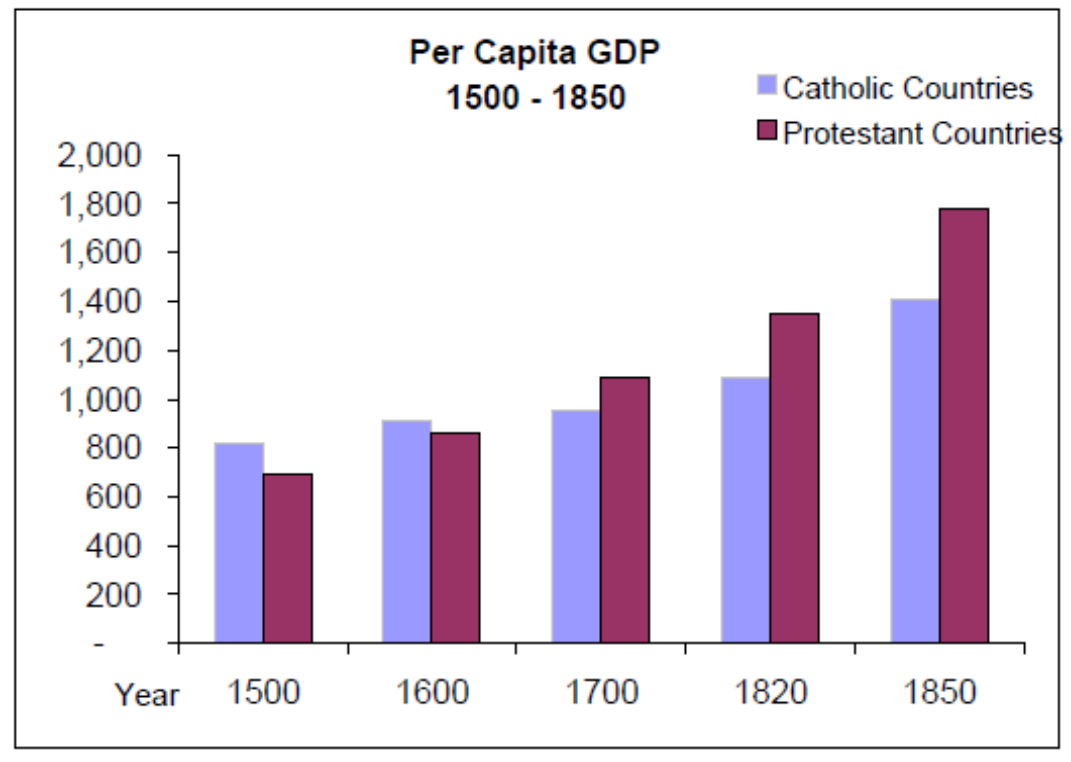

Source: Young's (2009:5) calculation on Maddison Database (2003)

\footnotetext{
${ }^{6}$ Austria, Belgium, France, Ireland, Italy, Portugal and Spain

${ }^{7}$ Britain, Denmark, Finland, Germany, Netherlands, Norway, Sweden and Switzerland
} 
For example in the modern era - according to the estimations - Italy did not show economic recovery, it remains stable around 1500 GK\$ per capita until the end of $19^{\text {th }}$ century. Meanwhile the Netherlands has already reached the Italian economic level on the turn of $15-16^{\text {th }}$ centuries and has an enormous growth until the beginnings of the $19^{\text {th }}$ century. Based on Weber's thesis, religious affiliation was the quint essence of economic development for both of them. As Young summarizes his calculations ${ }^{8}$ on Maddison database: "For more than 250 years, Catholic Europe lagged behind the Protestant countries by a substantial margin, averaging 27\% lower incomes between 1700 and 1960" (Young, 2009:10).

Naturally the development of Venice, which as a centrum area played key role in the European economy for centuries, has broken not only for religious reason but due to the effects of the Great Geographic Discoveries. The period of colonization favored Western European states like England and the Netherlands, whereas Venice stagnated. In a long run still those countries prospered which has got adequate economic culture for sustainable development, therefore prodigal states as Spain or Portugal - which were mainly Catholic could not keep their wealth from the Discoveries. Referring to the research of McCagg (1985) Protestants had considerable influence on industrialization which facilitated Dutch and English economic growth. Acemoglu and Robinson (2012) highlights the institutional differences between the mentioned countries (innovations at finances, contract law, commerce and other areas), which in my opinion generated from distinct religious and cultural background. I can confirm this statement with some instances.

The Roman Catholic church ruled economic activity with more rigorous instructions than Protestant denominations in the modern era. "Simony was condemned because it was viewed as the sale of Christ's charisma and usury was condemned because it was the sale of God's time" - says Rowell and Conelly (2012). Furthermore Pope Gregory IX. declared insurance as illicit transaction, while Portuguese (Carmelite Joao Sobrinho) and French (Pierre Tartaret) theologians enhanced the same conviction (Ceccarelli, 2001). These restrictions on business transactions limited economic activity and performance at the same time. In contrast with medieval tradition Luther did not condemned commerce at general, only the ungodly forms of this. He already permitted usury in the case of damage and loss of profit (Luther, 1983). Calvin was more permissive in this query, he lifted a ban on usury (Sebestyén, 1911). These Prostestant regulations have enabled institutional changes in the business sector, which contributed to the prosperity of Protestant countries.

\footnotetext{
${ }^{8}$ Young's calculation relies on per capita GDP of seven Catholic and eight Protestant countries.
} 
Figure 3 Catholic Economic Performance Relative to Protestant Regions.

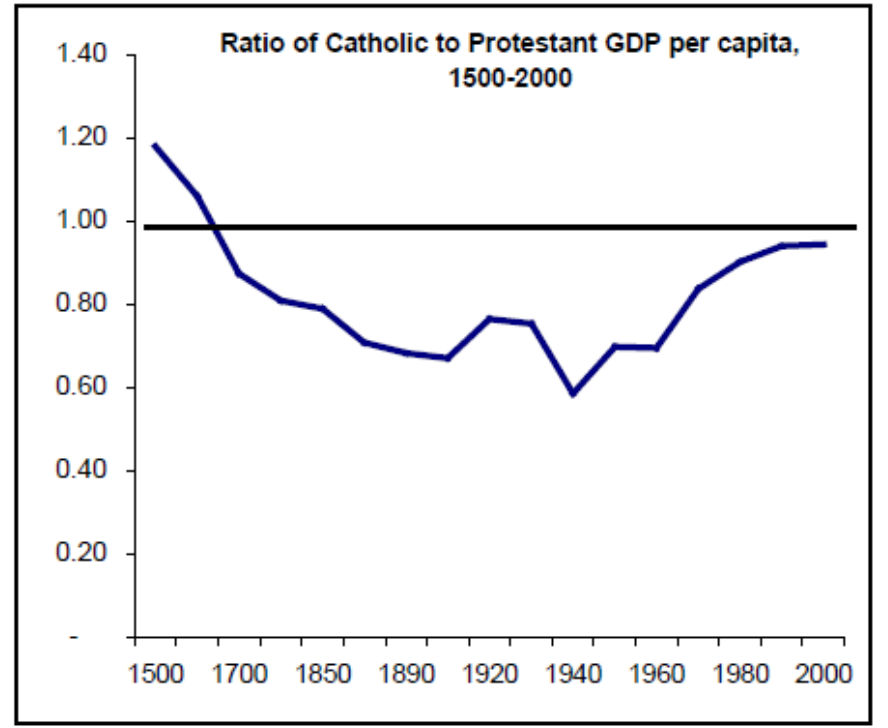

Source: Young's (2009:11) calculation on Maddison Database (2003)

Fig. 3 shows us the widening gap in the performance of Western European economies from the beginnings of the $18^{\text {th }}$ century. Only the convergence measures of the European Economic Community (1957-) reduced this inequality between Protestant and Catholic countries, according to Young's explanation (2009). The question is, how can we detect the distinctions between economic thinking of the examined countries? Are there any historical evidences or visual signs of cultural differences? The following part of the paper investigate that.

\section{RESULTS: ECONOMIC DEVELOPMENT THROUGH MODERN PAINTING}

Cultural differences firstly appear in the way of thinking, attitudes and lifestyle. The imaging of religiously inspired living is apparent in modern fine arts. For collecting more evidences about cultural and economic correspondences, the following part of the study compares Italian and Dutch religious paintings between the $15^{\text {th }}$ and $19^{\text {th }}$ centuries. ${ }^{9}$ The goal of this investigation to introduce those visual signs which foreshadow the differences in economic thinking of the mentioned countries.

Firstly I have collected Bible-themed paintings from an online database (ArtBible) ${ }^{10}$, where I've selected artworks from the modern era (15-19 ${ }^{\text {th }}$ centuries). The narrowed database contains 888 paintings with the detailed regional distribution in Fig. 4. After that I have

\footnotetext{
${ }^{9}$ Martin Luther made his declaration (the 95 theses) on October 31, 1517. The period of my investigation extended the beginnings of the modern era, which enable to analyse art before and after the Reformation.

${ }^{10}$ Of course there is not any online database which conclude the whole collection of Bible-themed paintings. The chosen one includes the most famous front-main painters and their works on the topic and some of the less known artists.
} 
chosen the artworks referring economic activities, and these ones became the subject of the investigation.

\section{Appearance of biblical topics in modern painting}

Probably man consider Italian frescos as major Bible-themed paintings from the modern era but there are more Dutch artworks in the examined period than Italian ones as it is pointed out on Fig. 4. Let us think about the extraordinary lifework of Rembrandt, Brueghel, Van Eyck or Van Gogh! They all verify the importance of Dutch fine arts in the period.

Figure 4 Territorial distribution of Bible-themed paintings, $15-19^{\text {th }}$ centuries

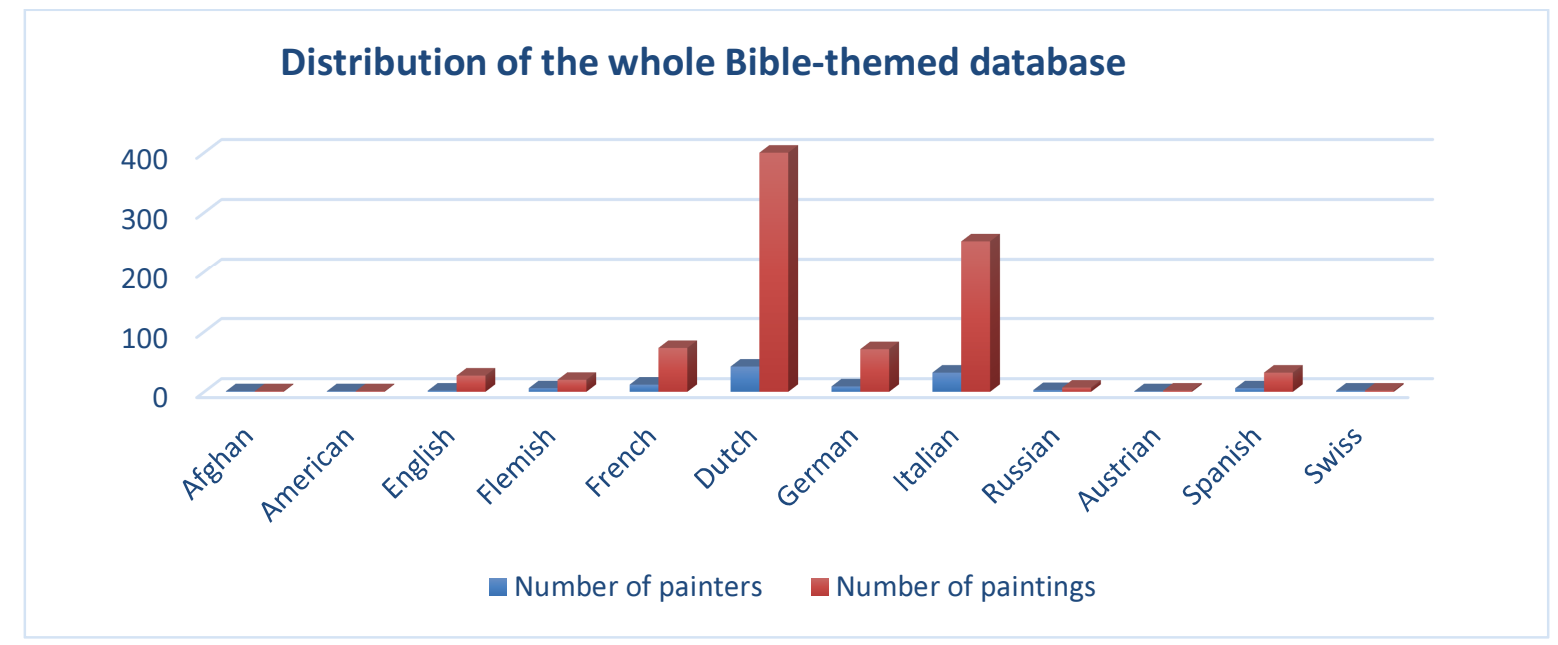

Source: Own edition

Most of the paintings process classical religious topics like the tower of Babel, the expulsion from the Garden of Eden, the life situations and messages of Jesus. The modern era proved to be a fruitful period in Christian art, when biblical topics came to be a popular field to apply brand new techniques. The freshly discovered geometrical method of perspective firstly presented by religious artworks in the Quattrocento such as the majestic painting of the Last Supper by Leonardo da Vinci or the Holy Trinity by Masaccio.

The main difference between Protestant and Catholic artists, that the latters created images more often for sacred usage, as decorations of temples and chapels. Protestants rejected the adoration of God in connection with religious images, some of their leaders - such as Calvin or Zwingli - encouraged to remove these images for prohibiting idolatry (they were called iconoclasts). Therefore Protestants regarded Christian art as more profane thing than Catholic people. The Council of Trent (in 1563) as the most determining event of CounterReformation, determined that religious art should be more focused on religious subject-matter 
and less on material things - like economic activities - and decorative qualities (IV. Pius, 1563). Italian painters according to the Twenty-fifth session of the decrees had to avoid everything that is profane and strengthen the holiness of the artworks.

Figure 5. The creators of Bible-themed works by the numbers of paintings with economic aspects

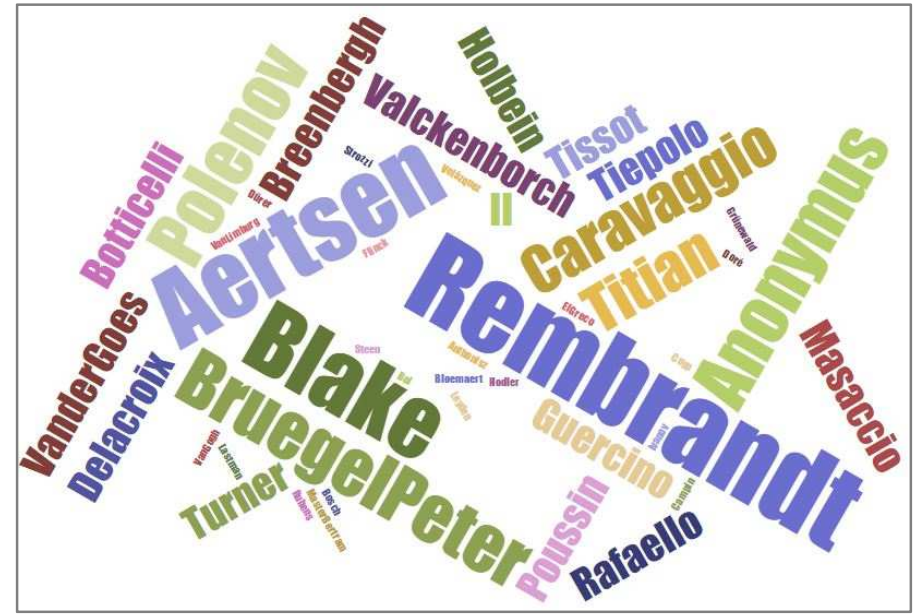

Source: Own edition

\section{Illustrating economic activities on religious paintings}

Furtherly I have examined all of the 888 paintings by content analysis and selected those ones, which illustrate economic aspects of the Bible stories. I have found 85 pieces of work concerning to some kind of market activities. The creators of the selected paintings is shown in Fig. 5, where the larger name connected to the more fruitful painters on the topic. Those painters excel markedly from the collection who originated from Protestant areas like Rembrandt, Aertsen, Blake and Pieter Brueghel the Elder. The list of the painters and their artworks which were the basis of the analysis is shown at the end of the paper.

There are three categories of the examined paintings: 1) illustration of concrete economic parable or message from the Bible, 2) representing economic activities from Biblical ages or 3) demonstrating traditionally religious topics in business environment (for example the crucifixion with a market scene). The Dutch painter Peter Aertsen is famous for his works related to the least category, such as the painting of "Christ and the Adulteress" in Fig. 6. At the first glance man can think that it is a secular painting about some market activities but a Biblical scene - which gave the title of the work - is illustrated in the background. 
Figure 6 Christ and the Adulteress by Peter Aertsen, 1559.

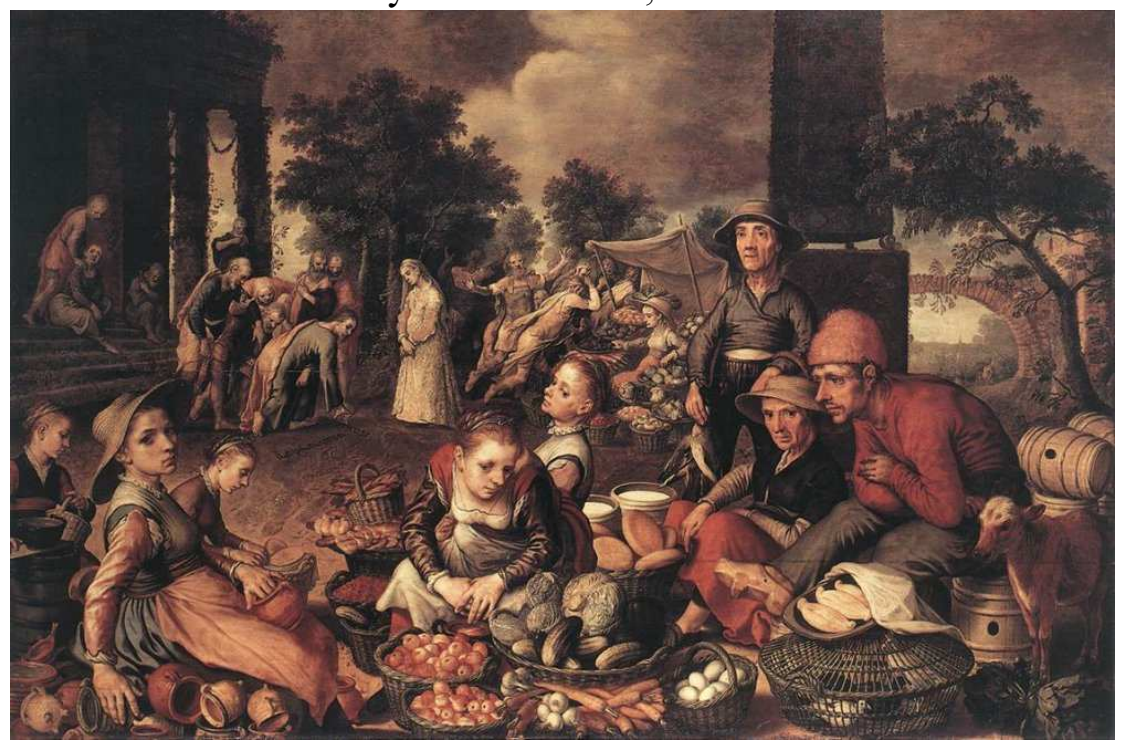

Source: ArtBible

The selected paintings with economic aspects connect religious topics with secular life. It is an interesting question whether Roman Catholic or Protestant painters tended to do this kind of artworks. As shown in Fig. 7, the number of Dutch paintings highly exceed the number of Italian ones and it originates from not only the larger rate of pieces from the Netherlands, because they have relatively the greatest number of this kind of artworks. Namely $9 \%$ of Bible-themed Dutch paintings represent economic or business activities, while Italian painters did the same only in $6.75 \%$ of the cases. In the time of reformation and the born of capitalism (mainly the $16-17^{\text {th }}$ centuries) this rate was $20 \%$ for the Netherlands (!) and it has been reducing for the following centuries. Meanwhile the rate of artworks with economic aspects did not changed in Italy, it remained stable at the mentioned level permanently. It points to the fact that in the $16^{\text {th }}$ and $17^{\text {th }}$ centuries religious way of life and economic activity linked more likely in Dutch culture, than in Italian one. The previously mentioned Catholic decrees from the Council of Trent give us sensible explanation for this result. 
Figure 7 Territorial distribution of Bible-themed paintings with economic aspects, $15-19^{\text {th }}$ centuries.

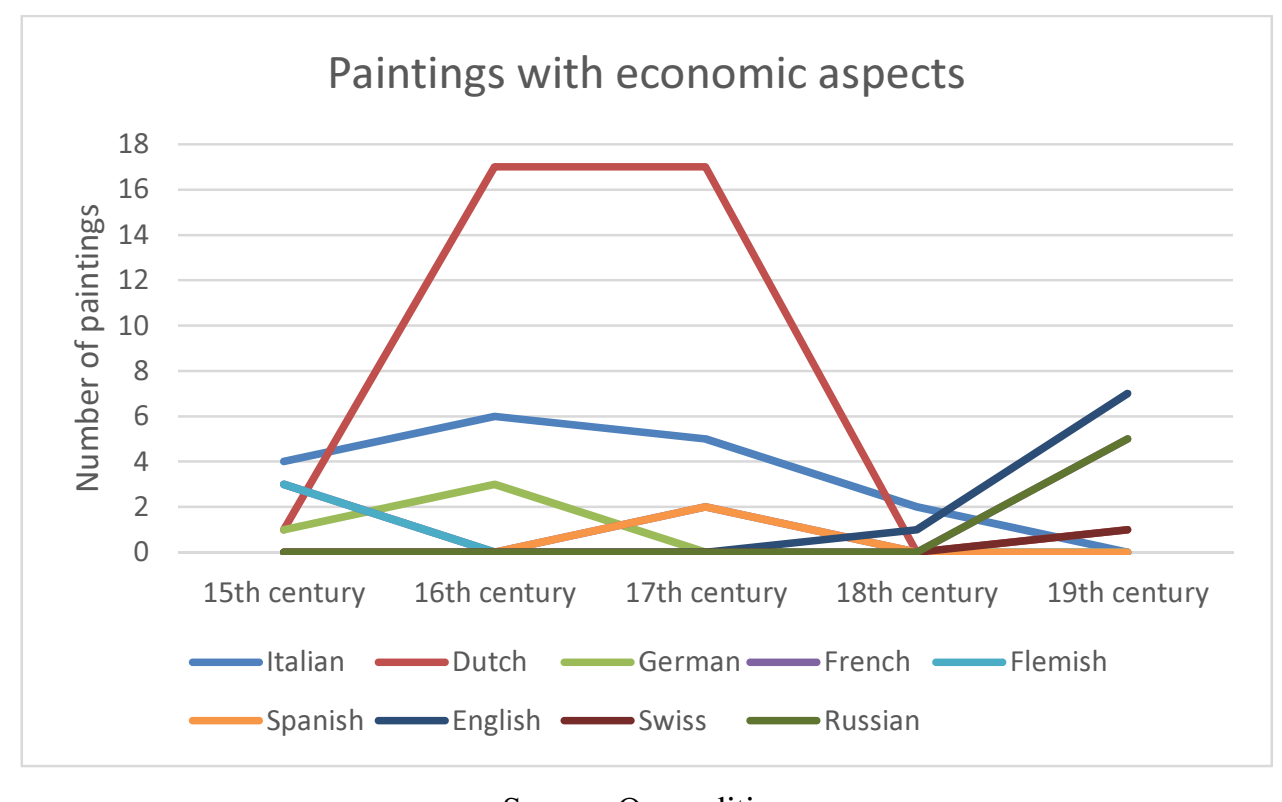

Source: Own edition

After quick selection and description we could examine the message of the paintings. The results of this study indicates that Dutch artworks are more pragmatist than Italian ones which latter illustrate mostly sentimental religious stories. In contrast artworks from the Netherlands often show Biblical persons as ordinary people in average life situations. Economic message of the paintings from the two regions also differ. Main economic topic of Dutch paintings are work, redistribution, market, investment and commerce (see at Fig. 8) - which all relate fundamentally to capitalist ideology and practice.

On the other side Italian religious and economic-themed artworks deal with taxation (payment and avoidance), divine providence, coveting, greediness and overconsumption. Instead of thinking about prosperity (as Protestants did) they pointed to the great market sins and the duties for the state. There is a huge difference between the two economic mentalities, because the first one encourages business activities and the latter one warns about it. The results of this investigation show that Dutch masters put market coordination, while Italians bureaucratic coordination into the canvas. 
Figure 8 Main economic topics of Dutch (on the left) and Italian (on the right) paintings
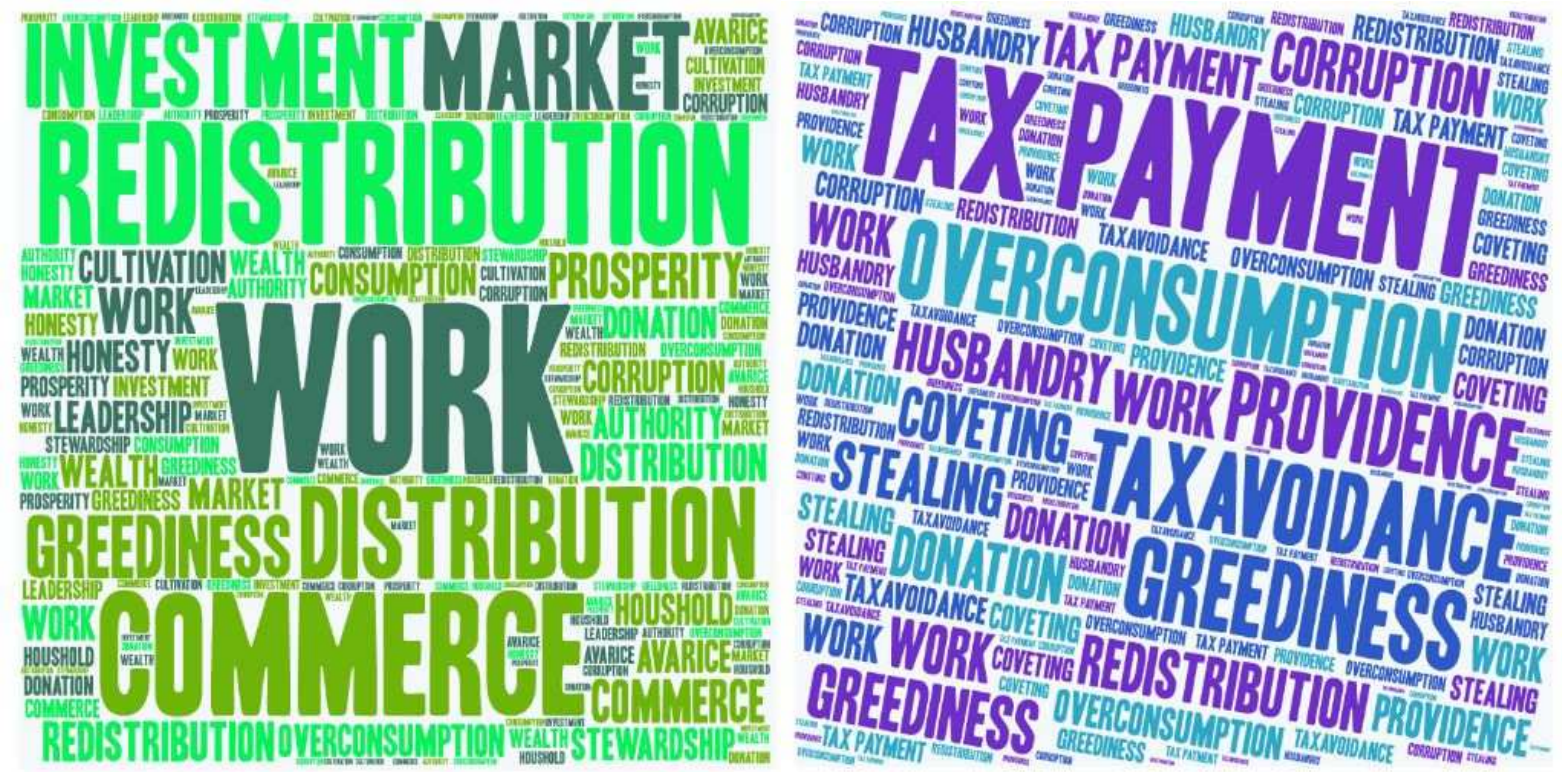

Source: Own edition

\section{CONCLUSION}

According to Max Weber's assumption, Protestant ethics is the key factor of economic differences between European countries in the modern era. This paper applied multidisciplinary approach to investigate the relevance of this theory by examining cultural and economic correspondences. Naturally, besides Weber's explanation, there are some alternative hypothesis about the connection between religion and modern European economic development. They include 1) the impacts of the Jewish community on innovating trade (Sombart, 1924; McCagg, 1985); 2) the importance of secularization by liberalizing economic activity from religious control (Tawney, 1926); 3) the great effects of Bible printing and education on literacy (Becker \& Woessmann, 2009, 2010), 4) the new business class established due to the access to Atlantic (slave) trade (Young, 2009, Acemoglu et al., 2005). The frames of this study do not allow discussing all of these opportunities, so it investigated the validity of Weber's thesis on a multidisciplinary field.

The main goal of the current study was to highlight the differences between Protestant and Catholic work ethic from fine arts of the modern period. In this way it collected Bible-themed paintings between $15^{\text {th }}$ and $19^{\text {th }}$ centuries (888 pieces) and separated those ones which relay also economic message (85 pieces). The findings of this study suggest that Protestant painters illustrated more likely religious topics in business environment than their Catholic 
contemporaries. Especially it characterized the Netherlands for the $16^{\text {th }}$ and $17^{\text {th }}$ centuries, when reformation had considerable influence on their society.

Regarding to the message of these religious and economic-themed paintings Italians concentrated on the good relationship with authorities (tax payment, corruption) while Dutch painters encouraged entrepreneurship and the movement of the invisible hand. The latter reflects to Protestant work ethic and the beneficial attitude for wealth gaining. The fine arts of the Netherlands represent the influence of this country on capitalism.

Although the study has successfully demonstrated the differences between the modern Italian and Dutch paintings, a number of important limitations need to be considered. On the one hand painters in the modern ages often determined by their customers (bankers, churches etc.), therefore it is possible that only a narrow part of the society declared the mentioned business values. For example the Adoration of the Magi by Sandro Botticelli has turned from sacramental illustration because it inserted Medici portraits on the canvas satisfying the needs of the family (Gila, 2006). From another angle it is true that Dutch painters were mostly Protestants and the Italians belonged to Catholic denominations, we could find odd men out. The Flemish Hugo van der Goes for instance moved to a monastery at the peak of his carrier (Gila, 2006) or Van Gogh disappointed in Christianity, even as a teenage he planned to be a minister of the Dutch Reformed Church as his father was (Erickson, 1998).

Whilst this study could not satisfactorily confirm the theory of Weber, it did partially substantiate his concept. These findings may provide several contributions to the current literature from an artistic perspective. This research demonstrated that economic processes can be examined from multidisciplinary approach, and some kind of economic theories are demonstrable in fine arts. It is recommended that further research be undertaken in the field for sociology of religion.

\section{Acknowledgement}

This publication is supported by the ÚNKP-17-3 New National Excellence Program of the Ministry of Human Capacities.

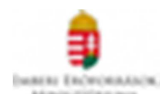

\section{REFERENCES}

Acemoglu, D. et al. (2005). The Rise of Europe: Atlantic Trade, Institutional Change, and Economic Growth. American Economic Review, 95 (3) 546-79.

Acemoglu, D. \& Robinson, J. A. (2012). Why Nations Fail: The Origins of Power, Prosperity and Poverty. New York: Crown Publising Group.

Arnot, C. (2011). Protestant vs Catholic: which countries are more successful? Retrieved from http://www.theguardian.com/education/2011/oct/31/economics-religion-research

ArtBible database. Retrieved from http://www.artbible.info/art/ 
Barro, R. J., \& McCleary, R. M. (2003). Religion and Economic Growth. American Sociological Review, 68, 760-781.

Barro, R. J. \& McCleary, R. M. (2006). Religion and Economy. Journal of Economic Perspectives, 20 (2), 49-72

Becker, S. O., \& Woessmann, L. (2009). Was Weber Wrong? A Human Capital Theory of Protestant Economic History. The Quarterly Journal of Economics, 124 (2), 531-596.

Becker, S. O. \& Woessmann, L. (2010). The Effect of Protestantism on Education before the Industrialization: Evidence from 1816 Prussia. Economics Letters, 107 (2), 224-228.

Calvin, J. (1585). An Abridgement of the Institution of Christian Religion. Edinburgh: Thomas Vautrollier.

Ceccarelli, G. (2001). Risky Business: Theological and Canonical Thought on Insurance From the Thirteenth to the Seventeenth Century. Journal of Medieval and Early Modern Studies, 31, 607-658.

Erickson, K. P. (1998). At Eternity's Gate: The Spiritual Vision of Vincent van Gogh. Grand Rapids (Michigan): William B. Eerdmans Publishing Co.

Gila, Z. (2006). Itáliai reneszánsz mesterek. Debrecen: Tóth Könyvkereskedés és Kiadó.

Gila, Z. (2007). Van Gogh. Tóth Könyvkereskedés és Kiadó, Debrecen.

Guiso, L., Sapienza, P. \& Zingales, L. (2003). People's Opium? Religion and Economic Attitudes. Journal of Monetary Economics, 50 (1), 225-82.

Guiso, L., Sapienza, P. \& Zingales, L. (2006). Does Culture Affect Economic Outcomes? Journal of Economic Perspectives, 20 (2) 23-48.

Kovács, G. (2004). A protestáns identitás és a „kapitalizmus szelleme”. In Czagány L. \& Garai L. (szerk): A szociális identitás, az információ és a piac. Szeged: SZTE Gazdaságtudományi Kar Közleményei, JATEPress, 105-123.

Krippendorff, K. (1995). A tartalomelemzés módszertanának alapjai. Budapest: Balassi Kiadó.

Luther, M. (1983). Asztali beszélgetések. Budapest: Helikon.

Maddison Database. Retrieved from http://www.ggdc.net/maddison/maddisonproject/data.htm

McCagg, W. O. (1985). A sikerhez vezető út. In Béládi et al. (szerk.): Zsidókérdés Kelet- és Közép-Európában. Budapest: ELTE-ÁJK, Fejlődés-tanulmányok, regionális sorozat 3. része.

Novak, M. (1994). A demokratikus kapitalizmus szelleme. Budapest: General Press Kiadó.

Pius IV (1563). The Council of Trent - The Twenty-Fifth Session. The canons and decrees of the sacred and oecumenical Concil of Trent. Retrieved from https://history.hanover.edu/texts/trent/ct25.html

Rogers, G. L. (szerk., 2004). Benjamin Franklin - Az erény művészete. Budapest: Bagolyvár Könyvkiadó.

Rowell, D. \& Connelly, L. B. (2012). A History of the Term „Moral Hazard”. The Journal of Risk and Insurance, 79 (4), 1051-1075.

Sebestyén, J. (1911). Kálvin és a kapitalizmus. Marosvásárhely: Kálvineum.

Sombart, W. (1924). Der moderne Kapitalismus. München-Leipzig: Duncker und Humblot.

Tawney, R. H. (1926). Religion and the Rise of Capitalism: A Historical Study. New York: Harcourt Brace \& Co.

Teacherweb. Religious divisions of Europe. Retrieved from http://teacherweb.ftl.pinecrest.edu/snyderd/mwh/projects/cov/maps/MapRel.htm

Young, C. (2009). Religion and Economic Growth in Western Europe: 1500-2000. Retrieved from:

http://web.stanford.edu/ cy10/public/Religion_and_Economic\%20Growth_Western_Eu rope.pdf 
Weber, M. [1920]. A protestáns etika és a kapitalizmus szelleme. Budapest: Gondolat, 1982.

Weber, R. P. (1985). Basic Content Analysis. Beverly Hills: Sage Publications.

\section{The examined artworks in alphabetical order:}

Aertsen (1559): Christ and the Adulteress

Aertsen (1553): Christ in the House of Martha and Mary

Aertsen (1575): The Miraculous Healing of a Lame Man by Peter and John

Aertsen (1575): The Seven Acts of Mercy

Aertsen (1550): Market Scene

Aertsen (1551): Butcher's Stall with the Flight into Egypt

Aertsen (1559): Cook in front of the Stove

Anthonisz (1547): The Fall of the Tower of Babel

Blake (1804): God answers Job

Blake (1795): Nebuchadnezzar

Blake (1826): The Book of Job - 01

Blake (1826): The Book of Job - 05

Blake (1826): The Book of Job - 14

Blake (1826): The Book of Job - 21

Bloemaert (1624): The Parable of the Wheat and the Tares

Bol (1661): Elisha refusing the gifts of Naaman

Bosch (1516): Haywayn triptych

Botticelli (1485): The Abyss of Hell

Botticelli (1482): The Temptation of Christ

Breenbergh (1655): Joseph Distributing Corn in Egypt

Breenbergh (1640): Christ and the Rich Young Ruler

Bruegel, Peter (1566): Census at Betlehem

Bruegel, Peter (1568): The Parable of the Blind

Bruegel, Peter (1563): The Tower of Babel (Rotterdam)

Bruegel, Peter (1563): The Tower of Babel (Vienna)

Campin (1428): Mérode Altarpiece

Caravaggio (1598): Martha and Mary

Caravaggio (1600): The Calling of Saint Matthew

Caravaggio (1607): The Seven Works of Mercy

Cuyp (1652): Joseph, the Butler and the Baker

Delacroix (1849): The Good Samaritan

Delacroix (1852): The Good Samaritan

Doré (1865): The Confusion of Tongues

Dürer (1497): The Prodigal Son among the pigs

El Greco (1600): Scourging the Moneychangers from the Temple

Flinck (1638): Isaac blesses Jacob

Grünewald (1515): Isenheim Altar

Hodler (1886): The Good Samaritan

Holbein (1538): Pharaoh's dream

Holbein (1543): Solomon receives the Queen of Sheba

Il Guercino (1619): The return of the prodigal son

Il Guercino (1655): The return of the prodigal son

Ivanov (1833): Joseph's Brothers Find the Silver Goblet in Benjamin's Sack

Lastman (1614): Abraham on the way to Canaan

Leyden (1530): The Adoration of the Golden Calf 
Masaccio (1425): Death of Ananias

Masaccio (1425): Rendering of the Tribute Money

Master of the Munich Golden Legend (1430): The animals leave the ark

Master of the Munich Golden Legend (1430):The Tower of Babel

Polenov (1900): And there was (The life of Christ)

Polenov (1874): Prodigal Son

Polenov (1900): John and James

Polenov (1911): The limits of tyre

Poussin (1652): Death of Sapphira

Poussin (1664): Summer (Boaz and Ruth)

Rafaello (1516): The Death of Ananias

Rafaello (1516): The Miraculous Draught of Fishes

Rembrandt (1635): Belshazzar's Feast

Rembrandt (1645): Boaz pouring Six Measures of Barley into Ruth's veil

Rembrandt (1648): Esau sells his Birthright to Jacob

Rembrandt (1657): Jesus preaching

Rembrandt (1655): Joseph Accused by Potiphar's wife

Rembrandt (1629): Judas returns the silver coins

Rembrandt (1633): The Good Samaritan at the Inn

Rembrandt (1636): The Prodigal Son wastes his Inheritance

Rembrandt (1627): The rich fool

Rubens (1625): Abraham meets Melchizedek

Steen (1679): Adoration of the shepherds

Strozzi (1640): The Conversion of Zacchaeus

Tiepolo (1742): The gathering of manna

Tiepolo (1742): The sacrifice of Melchizedek

Tissot (1882): The prodigal son in modern life: the return

Tissot (1862): The return of the prodigal son

Titian (1508): The flight into Egypt

Titian (1515): The tribute money

Titian (1568): The tribute money (London)

Turner (1800): The fifth plague of Egypt

Turner (1800): The tenth plague of Egypt

Van der Goes (1475): Adoration of the Magi

Van der Goes (1475): Rachel and Jacob

Van-Gogh (1890): The Good Samaritan

Van-Limburg (1409): Announcement to the shepherds

Valckenborch (1568): The tower of Babel

Valckenborch (1594): The tower of Babel

Velázquez (1620): Christ in the House of Martha and Mary 